\title{
The Relationship between the Implementation of Parent's Educative Right and the Inheritance of Culture
}

\author{
Jingwen Wang \\ Chongqing University of Education \\ Chongqing, China
}

\begin{abstract}
From the historical development and the view of the world, parent's educative right does exist for a long time, but in the practice of education in China especially in the minority areas, it is forgotten now. The survey found that education can be internalized into the cultural heritage and the protection of people's spiritual level. Thus, family education, cooperates and coordinates with school education and community education will achieve education maximization commonly, and the implementation of parental educational rights provides another angle of view for national cultural heritage: the implementation of parent's educative right means the unity and cooperation of family education, school education and community education; parent's educative right can promote the implementation of the psychological inheritance of national culture, foster a sense of national identity; the implementation of parent's educative right means greatly promotes the process of the rule of law in ethnic regions.
\end{abstract}

Keywords-parent's educative right; ethnic groups; cultural heritage

\section{INTRODUCTION}

Parental education right is a general term for the rights and obligations of parents based on certain beliefs and values. In brief, parental education right is the right to educate their children. Therefore, parental education right includes not only the implementation of the law that should protect its leading role in family education, and should enjoy rights based on the relationship in community education and school education[1] .investigation of Tujia in Changyang Tujia Autonomous County, Hubei Province, Chongqing Youyang Tujia and Miao Autonomous County, Shizhu Tujia Autonomous County of ethnic regions found that living in the mountains of Wuling Tujia nationality, language, folk art, present situation and clothing of national culture inheritance, such as Tujia folk songs, folk songs in Youyang Tujia Waving Dance, Huaguzi, windmusic, sayerhe dance, folk songs, folk tales and lion dance loss, although the state and local governments have taken a series of measures to protect Tujia culture such as the establishment of ecological protection zone and, to a certain extent, develop cultural protection and inheritance channels, but these means more stay on a material level, it is not internalized into people's spiritual level, such as the formation of a strong sense of national pride and a sense of identity. An important channel of promoting national culture internalization is education, which mainly includes family education, school education and community education. The author thinks that the protection of the implementation of parental education right can provide a new perspective for the inheritance of ethnic culture.

\section{THE CULTURAL INHERITANCE IN ETHNIC AREAS REQUIRES THE COORDINATED COOPERATION OF FAMILY EDUCATION, SCHOOL EDUCATION AND COMMUNITY EDUCATION}

The richness and particularity of Tujia national culture education determine that the form of education must be diverse. The survey found that Tujia people have spoken scanty, only a few old people can say a few words, while young people almost no one can say native language; a lot of Tujia folk songs, Changyang Nanqu and traditional skills are on the verge of extinction; a large number of valuable data with historical and cultural value almost lost. As of now very few people will consciously wear traditional Tujia costumes, generally only in the remote mountainous area, where the elderly in holiday dress, even in some areas of Tujia nationality has been difficult to find a complete set of Tujia ethnic costumes, most young people love fashion on TV.

As there is no written language of the Tujia nationality, the unique national history and culture and the production of common sense of life must rely on oral education, so oral education plays an important role in Tujia nationality education. However, oral education is difficult to implement in the formal school education, only rely on family education or community education. In addition to the parents for the family education of the learners have historical origins: natural history, school education in ethnic minority areas arose late, cultural heritage is mainly rely on the community and family to carry out.

School education is the modern social cultural center of our center, and also the key of the cultural education system, the survey found that in Youyang Tujia and Miao Autonomous County, most of students think that the main source of Tujia ethnic cultural knowledge is now the only school education; school requirements when wearing Tujia 
costumes. In Hubei Changyang, many secondary schools trying to develop school-based curriculum, such as Bashan dance and sayerhe dance into the school physical education curriculum, and to carry out such as national culture into the campus, campus folk artists on the podium" and other cultural activities, the spread of Changyang - "Tujia folk songs such as art and culture.

Therefore, school education has indeed promoted the spread of national culture to a certain extent. However, due to limited material and human resources, national education schools tend to relatively simple, boring, education effect is not obvious: minority students still Lack of deep affection for the nation, lack of aesthetic knowledge and emotional resonance for a long history of traditional costumes and contains folk dance in history. the investigation found that Although the campus activities are relatively rich, but most of the time just look lively, some people even think that the performances are old and obscure, the native language is difficult to understand, but also the lack of professional staff to explain, so cannot form interactive and interest.

Thus, in order to promote the Tujia nationality systematically and effectively cultural heritage, to rely solely on the textbook as the carrier, the school education system of collective teaching is not enough; the deep culture of ethnic identity and national pride is more need of family education the migration of rich resources and provide the community education.

\section{THE IMPLEMENTATION OF PARENTAL EDUCATION RIGHT MEANS THE UNITY AND COOPERATION OF FAMILY EDUCATION, SCHOOL EDUCATION AND COMMUNITY EDUCATION}

Parent's educative right means that implements the contradiction between family education and school education, community education has been solved, and the formation of the security mechanism in the law, not only can the parents influence on children's function to the largest, fully embodies the legal social respect for natural rights, but also to build a bridge between family education and other education that will penetrate the excellent traditional culture to the school, many aspects of community education, education will influence on individuals throughout all aspects of education.

Parent's educative right means not only the right of parents to educate their children in the family, but also the right of parents to school education [2]. Specifically, the rights in substantive law mainly include two important aspects: first, parents' right to choose education, mainly to select the school curriculum, teaching methods, teachers and other freedoms. Two is the right of parents to participate in education, mainly including the right of participation and the right to know about the educational administrative departments and school educational decision-making, and the right to participate in the school education, such as teaching content and teaching methods. In school education, parents are often in the passive position as the subject of obligation, while school administrators and teachers are often the subject of rights and active. Parents rely solely on the needs of educational administrators to carry out certain behaviors. They are subordinate to one subject, which is subject to obedience, and not subject to equal contractual relations [1]. plus, Chinahave always been the traditional virtue, honor the teacher and respect his teaching to the teacher's respect and obedience will lead to parents in the school education of voice, even if the parents are trying to teach, and once the school education has the conflict contradiction, instinctively shrink, yield to teachers and education administration management department.

Second, the implementation of parental education means change in the role of parents in community education. In the past community education, parents play the role of an audience more. As in the Changyang area, the local government will host the annual large-scale community activities, the original ecological folk Changyang Nanqu, Changyang Tujia folk songs works written on display, promote community people's understanding of the importance of national culture, and promote the value and protection of the cultural heritage of the existence. However, in this activity, parents often just spectators, lack of emotional resonance, some people think: a lot of community activities such as marriage, have been away from the original memory, have lost due to the folk meaning; many folk dance has been in accordance with the contemporary aesthetic fashion shallow to transform, has been regarded as one kind of tourism earnings display tool on the surface looks very lively, but is actually the nature of damage to national culture.

The implementation of parent's educative right is a key to establish parental rights subject status, but also the reform of school bureaucracy characteristics, necessary conditions to ensure the full realization of the right to education of students, is an important guarantee to promote the healthy development of community culture. Parent's educative right implementation, can make the right of parents education from the natural right concept to legal rights, and then become the parents to enjoy the real rights, means that the construction and arrangement of parents can legally participate in the school curriculum and activities in the community, the school and the community will respect the views of parents, and the formation of channels and mechanisms related to attract parents the educational wisdom.

\section{THE IMPLEMENTATION OF PARENTAL EDUCATION Right CAN PROMOTE THE PSYCHOLOGICAL INHERITANCE of NATIONAL CUlTURE, AND CULTIVATE THE SENSE OF NATIONAL IDENTITY FROM AN EARLY AGE}

The survey shows: Tujia young man was finished a high degree of self-identity is not strong, the psychological cultural heritage of the poor, some people even think that the minority is relatively backward economy and culture is not advanced edge of the nation, so will be finished. Cultural inheritance refers to the process of a baton like vertical handover among community members in a common community of nations [3].Cultural heritage is the basic mechanism of cultural inheritance of ethnic cultures, ethnic culture is the intrinsic motivation of the community, the most stable and durable, is the core of psychological inheritance is to identity and culture with psychological inheritance constitute the core part of national identity. 
In 2014, the CPC Central Committee, the State Council issued the several opinions on Ideological and moral construction of minors to further strengthen and improve clearly pointed out: the family education plays an important role in the ideological and moral construction of minors. Parents run the school is an important starting point to enhance the level of family education, parents must strengthen the self-construction of the school development, to continuously improve the level of family education so that parents, family education has a multiplier effect. Research shows that family education and community education is the starting point of cultivating personal values, the person's life will have a lasting impact, in many ethnic minority areas, priests, elders, community residents and parents to educate the younger generation through enculturation etc. Enculturation is part of the conscious and unconscious part of the learning process, by the old generation of instructions, guidance and forced the younger generation to accept the traditional way of thought and behavior [4]. In the enculturation, elders, community residents and parents by religious and ceremonial means and the national culture values and ideas passed to the next generation, they help the formation of original belief.

In this way, the younger generation will form the corresponding psychological structure in this unique family ceremony, and combine the content of the national culture around the values, and form a community. Such as the Changyang area sayerhe dance is a kind of funeral dance is a kind of death, experience of life, conveys the Tujia people optimistic outlook on life and values, in the enculturation, the younger generation can understand and feel the cultural attitude, so as to further the formation of the national sense of identity.

\section{THE IMPLEMENTATION OF PARENTAL EDUCATION Right MEANS THE GREat PROGRESS OF THE RULE OF LAW IN ETHNIC AREAS}

Parent's educative right is a natural right, a universal right inherent in nature, and not limited to law or belief. However, in the education of ethnic areas in China, the right to parental education is often neglected. The implementation of parental education right means that great progress has been made in the rule of law in ethnic areas.

From the geographical distribution of speaking, the minority areas are often underdeveloped productivity, economic backwardness, productivity determines the superstructure, so the legal consciousness of ethnic minority areas generally indifferent, and for the local custom or customary law is more comply with the convention. For many families, although most parents are aware of their own rights and obligations have to discipline their children, educate their children more focused on "education" and "teaching", behoove that education should of course be the responsibility of the school, so it is difficult to form active education awareness and action. In the parent card of the United States, it has been made clear by substantive law that parents enjoy many rights in school education, such as parental choice of schools and right to participate in school education. The rationality of parents' educational authority illustrates the justification of parents' right to educate their children. This legitimacy means that the right to education of parents is recognized and protected by law, and thus obtains the right to exercise educational behavior freely within the legal scope. The laws and regulations of the Universal Declaration of human rights and many countries including China have been given the rights and duties of parents to educate their children, such as the Universal Declaration of human rights twenty-sixth paragraph third: many parents shall be given to their children's education, have the priority right to choose. The parent's educative right has become a real right for all parents [5].

In China, the implementation of the diverse demands of parents right of education not only means that the option to protect children's right to learn and respect their parents and meet the demand of education, it is an important manifestation of the legal construction of China, in order to promote the process of rule of law in Ethnic Regions, on the development of national culture, promote cultural identity, promote national unity, safeguard national unity, build a harmonious community, maintaining the cultural diversity of the world, promoting the common development of mankind has important significance.

\section{CONCLUSION}

In conclusion, parents' education can promote the coordination between family education, school education and community education, can promote psychological inheritance of national culture, cultivate national identity since the childhood, can also promote the development of region under the rule of law.

\section{ACKNOWLEDGMENT}

This study was funded by Chongqing Social Science Planning Project (2016py62). By the key research base of the humanities and Social Sciences in Chongqing urban and Rural Teacher Education Research Center Funding for tender subject (JDND201704). By Chongqing education science "13th five-year plan" plan for 2017 (2017-GX-341.) By Science and Technology Collaborative Innovation Platform: Family Education Research Center for Children aged 0-6.

\section{REFERENCES}

[1] X. Li, L. Xia, "A jurisprudential analysis of the existence of parent's educative right," Journal of Lanzhou University (Social Science Edition), vol. 3, pp.26, 2014.

[2] L. Yin, "On the content of parental education right from the perspective of comparative education and legal history," Comparative Education Research, vol. 11, pp8., 2001.

[3] S. Zhao, Outline of the cultural heritage of ethnic minorities in Yunnan, Kunming: Yunnan Nationalities Press, p. 17,2002.

[4] J. Zheng, Educational and cultural studies, Beijing: People's education press, p. 112,2000.

[5] L. Yin, On the boundary and content of parental education right, Education research, Tsinghua University. vol. 10, pp.35,2012. 